\title{
A note on the occurrence of lichens on Vainateya Godavari mangroves in East Godavari district of Andhra Pradesh India
}

\author{
Vinay Bharadwaj T*, Girija Sastry V and Murthy KS
}

University College of Pharmaceutical Sciences, Andhra Pradesh, Visakhapatnam - 530 003, India.

Vinay Bharadwaj T, Girija Sastry V, Murthy KS 2018 - A note on the occurrence of lichens on Vainateya Godavari mangroves in East Godavari district of Andhra Pradesh India. Studies in Fungi 3(1), 302-308, Doi 10.5943/sif/3/1/30

\begin{abstract}
During the collection of manglicolous lichens for the project work on pharmacological evaluation, three lichen species collected from a remote "Lanka" in less known Vainateya Godavari river basin in the year 2015. There is no record of any of these lichen species on the mangroves of Andhra Pradesh like Dirinaria consimilis (Stirton) D. D. Awasthi, Parmotrema tinctorum (Despr. ex Nyl.) Hale and Roccella montagnei Bel. em. D. D. Awasthi on the host is Excoecaria agallocha. Interestingly the authors find no such lichen flora even in the Coringa wild life sanctuary the second largest stretch of mangrove forests of India due to its close proximity to the port city of Kakinada.
\end{abstract}

Key words - Andhra Pradesh - manglicolous lichens - mangrove - new records

\section{Introduction}

Since Roxburgh (1814) to till date there have been many publications on various aspects of mangrove regions of India such as faunal, floral, ecological and microbiological, etc, while mangroves an abode for unique lichens have received poor attention (Awasthi 2007, Mohan \& Hariharan 2000, Jagadeesh et al. 2012). As far as is gathered nothing absolutely has so far been reported on the occurrence lichens on the mangroves of Andhra Pradesh state while there have been a few from the states of West Bengal, Odisha and Tamil Nadu on the east coast of India and on the biosphere of Sundarban, West Bengal \& some regions of Andaman \& Nicobar islands (Awasthi 2007, Panda et al. 2017).

Lichens are composite organisms formed by the symbiotic association of a fungus (mycobiont) and an algal (photobiont) or a cyanobacterium (cyanobiont). While the fungal element provide shape and structure the alga or cyanobacterium supply carbohydrates. Depending on the vegetative body (thallus structure) of lichens are broadly divided into three categories - crustose, foliose and fructose. Further lichens are either macrolichens or microlichens based on their growth form (Awasthi 2007). Lichens are not parasites as they produce their own food by photosynthesis (Jagadeesh et al. 2012). They are epiphytes use plants (arboreal), rocks (lithophytic), soil (terrestrial) etc. as substrates. In India, no detail study on mangrove associated lichens were recorded, besides that few works like Sudarban mangroves (142 lichen species), Muthupet mangroves (8 lichen species) and Andaman \& Nicobar islands (5 lichen species) (Awasthi 2007, Logesh et al. 2012, Panda et al. 2017). 


\section{Materials \& Methods}

Godavari enters plains at Polavaram, below Rajamahendravaram (Rajahmundry) at Vijjeswaram the river divides into two major distributaries - Goutami and Vasishta while the Goutami flows into the sea through two mouths, one near Bhairavapalem and the other near Kothapalem the Vasishta after travelling further downstream gives rise to Vianateya at P. Gannavaram. The Vasishta Godavari joins the bay at Antarvedi while the Vainateya debouches into the sea at Odalarevu. The river systems of Vasishta and Vainateya before entering the sea with creeks and canals form several mud flats and tidal mangrove forests forming an estuarine complex. The Lanka the last land mass in the Vainateya River nearest to the bay is the lone place wherein the manglicolous lichens in abundant quantities are found. The study area is situated within the coordinates of $16^{\circ} 44^{\prime} \mathrm{N}$ and $81^{\circ} 98^{\prime} \mathrm{E}$. Boat traverses were made to reach the "Lanka" during collection.

All the specimens collected were studied for their morphology, anatomy and identified at National Botanical Research Institute (CSIR-NBRI), Lucknow (LWG), India by using dissecting and Olympus BX-50 compound microscopes and compared with most recent literature available on lichen taxonomy. Chemical analysis was conducted by using thin layer chromatography and colour spot tests as described by Orange et al. 2010. The prepared herbariums have collected species with label number having species name, locality and altitude, collected date, collector's name and notes and deposited in the Lichen and Bryophyte Herbarium of the Council of Scientific and Industrial Research-National Botanical Research Institute (CSIR-NBRI), Lucknow (LWG), India.

\section{Results}

Dirinaria consimilis (Stirton) D. D. Awasthi

Figs 1A, 2A, S1A

Etymology - Physcia consimilis Stirt.

三 Bibliotheca Lichenologica 2: 1-108 (Caliciaceae).

Sample collected on Excoecaria agallocha at India, Andhra Pradesh, East Godavari District, Vainateya Island, 16 $44^{\prime} 48^{\prime} ' \mathrm{~N}$ and $81^{\circ} 98^{\prime} 19^{\prime}$ 'E (0 m elevation), 09 February 2015, (collector) T. Vinay Bharadwaj, herbarium number: 15-027173, Material examined and deposited at India, Lucknow, National Botanical Research Institute, Lichenology Laboratory (Fig. S2).

Description: Life habit: lichenized; Thallus: foliose corticolous, grey-white, $5-13 \mathrm{~cm}$ wide. Lobe surface: radiating, contiguous, 0.5-2.5 mm wide. Upper surface grey, bluish grey to off-white. Medulla: white in the upper part; lower medulla \pm orange towards the apices. Apothecia: sessile, 0.5-1.0 mm wide. Epihymenium pale brown, 9-10 $\mu \mathrm{m}$ thick. Hymenium: colourless, 70-80 $\mu \mathrm{m}$ thick. Hypothecium dark brown to brown-black, lentiform, 180-200 $\mu \mathrm{m}$ thick. Ascospores: 14-23 $\times$ 6-8 $\mu \mathrm{m}$. Conidia bacilliform: 4-5 $\times$ 0.8-1.0 $\mu \mathrm{m}$.

Chemistry: Cortex K+ yellow, P+, KC-, C- yellow; medulla K-, C-, KC-, P-.

Parmotrema tinctorum (Despr. ex Nyl.) Hale

Figs 1B, 2B, S1B

Etymology - Parmelia tinctorum Despr. ex Nyl.

三 Phytologia 28: 339, 1974 (Parmeliaceae).

Sample collected on Excoecaria agallocha at India, Andhra Pradesh, East Godavari District, Vainateya Island, $16^{\circ} 44^{\prime} 77^{\prime} ' \mathrm{~N}$ and $81^{\circ} 98^{\prime} 19^{\prime}$ 'E (0 m elevation), 09 April 2016, (collector) T. Vinay Bharadwaj, herbarium number: 16-027176, Material examined and deposited at India, Lucknow, National Botanical Research Institute, Lichenology Laboratory (Fig. S3).

Description: Life habit: lichenized; thallus loosely adante, $10-30 \mathrm{~cm}$ wide. Lobes irregular, 10-15 mm wide. Upper surface pale green to grey-green. Medulla white. Lower surface smooth, shiny, black, rhizines sparse, simple, coarse, short, $0.5-2 \mathrm{~mm}$ long. Apothecia very rare, 8-20 mm wide. Ascospores: 14-16 × 6-7 $\mu \mathrm{m}$. Pycnidia rare. Conidia filiform, 10-13 × 1.0 $\mu \mathrm{m}$.

Chemistry: cortex $\mathrm{K}+$ yellow, medulla $\mathrm{K}-, \mathrm{C}+\mathrm{red}, \mathrm{KC}+\mathrm{red}, \mathrm{P}-$. 
Etymology - Roccella montagnei Bél.

三 Cladistics 23: 10-11, 2007 (Roccellaceae).

Sample collected on Excoecaria agallocha at India, Andhra Pradesh, East Godavari District, Vainateya Island, $16^{\circ} 44^{\prime} 59^{\prime} ' \mathrm{~N}$ and $81^{\circ} 98^{\prime} 19^{\prime}$ 'E (0 m elevation), 24 December 2014, (collector) Murthy KS, herbarium number: 14-027172, Material examined and deposited at India, Lucknow, National Botanical Research Institute, Lichenology Laboratory (Fig. S4).

Description: Life habit: lichenized; thallus: corticolous, fruticose, up to $20-25 \mathrm{~cm}$ tall. Lobe Surface: glaucous green to yellowish grey. Medulla: white, fronds dichotomously and profusely branched, at the basal part expanded to $5-10 \mathrm{~mm}$, branches gradually tapering to $1 \mathrm{~mm}$ or less, ca. $0.6 \mathrm{~mm}$ thick, lacinules often present on major branches, surface smooth to lacunose. Thallus white, orbicular, 0.5-1.0 mm wide, soredia 40-50 $\mu \mathrm{m}$. Apothecia absent. Cortex: palisade hyphae at right angles to the longitudinal axis of thallus. Alga trentepholia.

Chemistry: Cortex K-, C+ red, P-; medulla K-, C-, P-; soralia C-.
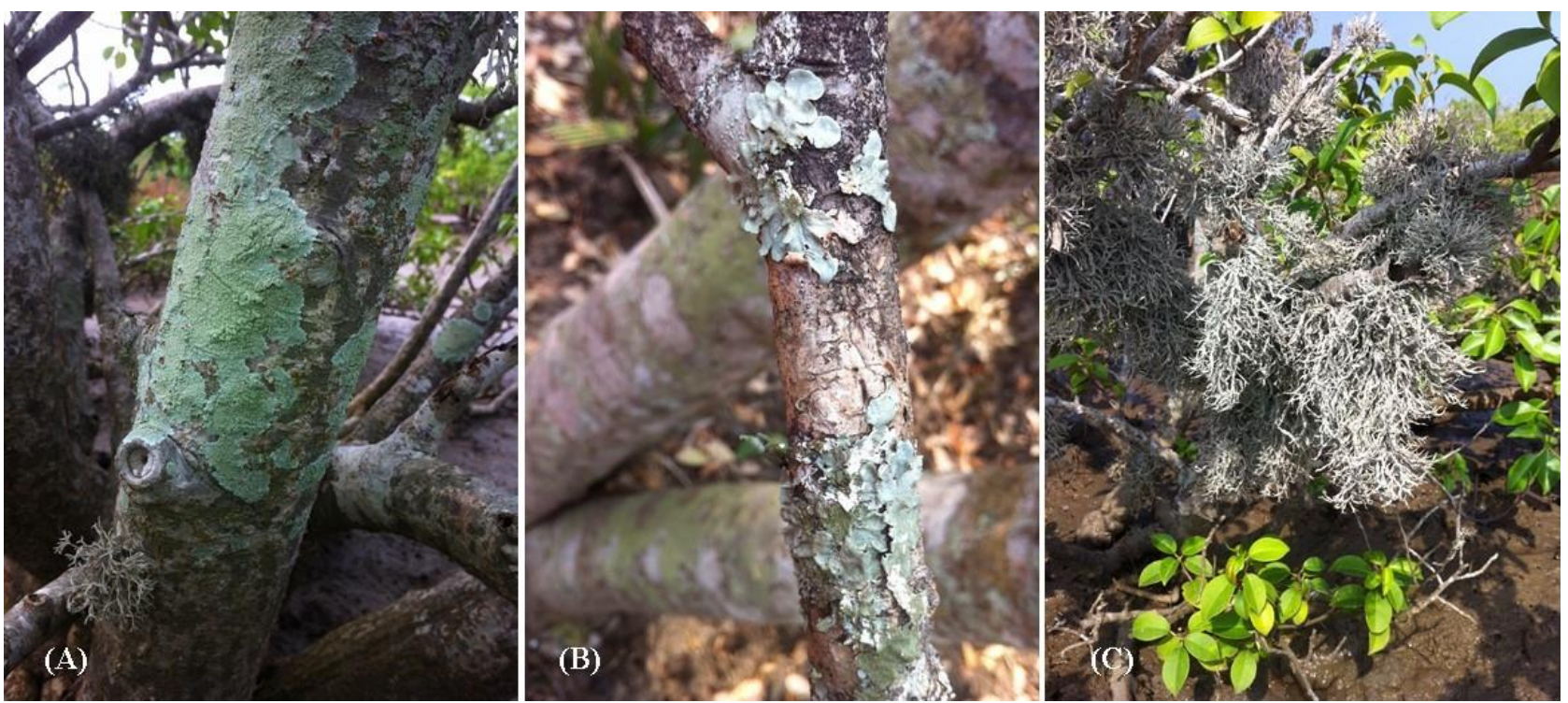

Fig. 1 - Images of A Dirinaria consimilis (Stirton) D. D. Awasthi. B Parmotrema tinctorum (Despr. ex Nyl.) Hale. C Roccella montagnei Bel. em. D. D. Awasthi. Scale Bars: A, B, C = $1 \mathrm{~cm}$
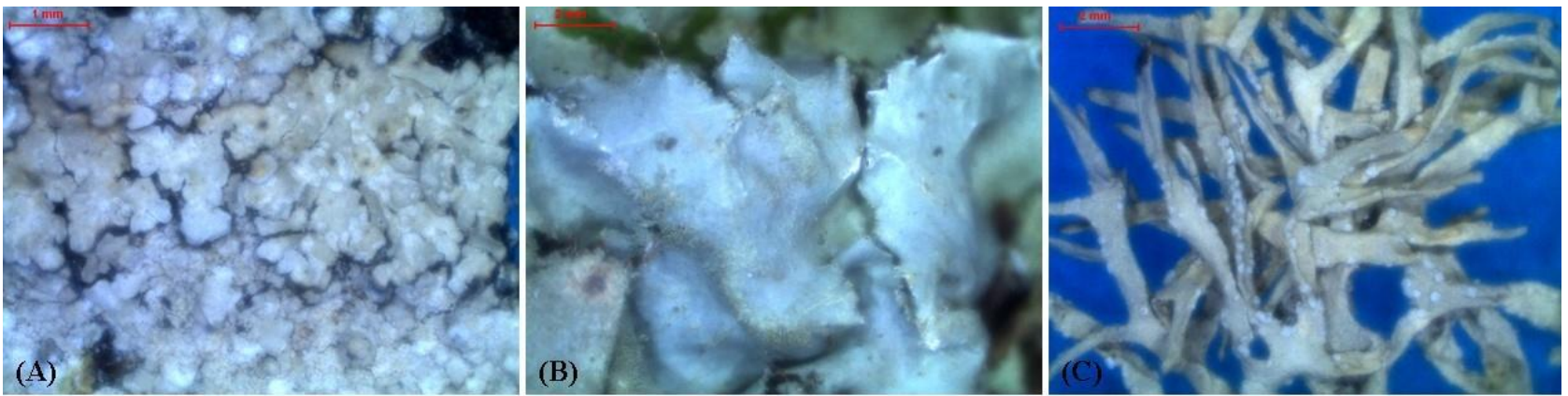

Fig. 2 - Microscopic images of A Dirinaria consimilis (Stirton) D. D. Awasthi. B Parmotrema tinctorum (Despr. ex Nyl.) Hale. C Roccella montagnei Bel. em. D. D. Awasthi. Scale bars: A = 1 $\mathrm{mm}, \mathrm{B}, \mathrm{C}=2 \mathrm{~mm}$.

\section{Acknowledgements}

This work was financed by the Ministry of Earth Sciences, New Delhi, India. We thank Dr. D. K. Upreti, Lichenologist, CSIR-NBRI, Lucknow for identification and storage of specimens. 


\section{References}

Awasthi DD. 2007 - A compendium of the macrolichen from India, Nepal and Sri Lanka. Bishen Singh Mahendra Ral Singh, Dehra Dun, India.

Jagadeesh Ram TAM, Sinha GP, Singh KP. 2012 - Lichen flora of Sundarbans Biosphere Reserve, West Bengal. Dishen Sigh Mahendra Pal Shingh, Dehra Dun. pp: 384.

Logesh AR, Upreti DK, Kalaiselvam M, Nayaka S, Kathiresan. 2012 - Lichen flora of Pichavaram and Muthupet mangroves (Southeast Coast of India). Mycosphere (DOI: 10.5943/mycosphere/3/6/1)

Mohan MS, Hariharan GN. 2000 - Lichen distribution pattern in Pichavaram - A preliminary study to indicate forest disturbance in the mangroves of South India. In: Biology of Lichens. Mukerji KG, Charmola BP, Upreti DK and Upadhyay RK (eds.), Aravali Books International, New Delhi, India, pp: 283-296.

Orange E, Lumbsch HT, Elix JA. 2010 - Microchemical methods for the identification of lichen substances, (II eds.), British Lichen Society, London, pp. 475-479.

Panda M, Murthy TVR, Samal RN, Lele N et al. 2017 - A comparative study of manglicolous lichens and their distribution inside Bhitarkanika National Park (Odisha), India. Studies in Fungi, 2(1), 1-13.

Roxburgh W. 1795-1819 - Plants of the coast of Coromandel (3 vols.) London.

\section{Supplementary information}
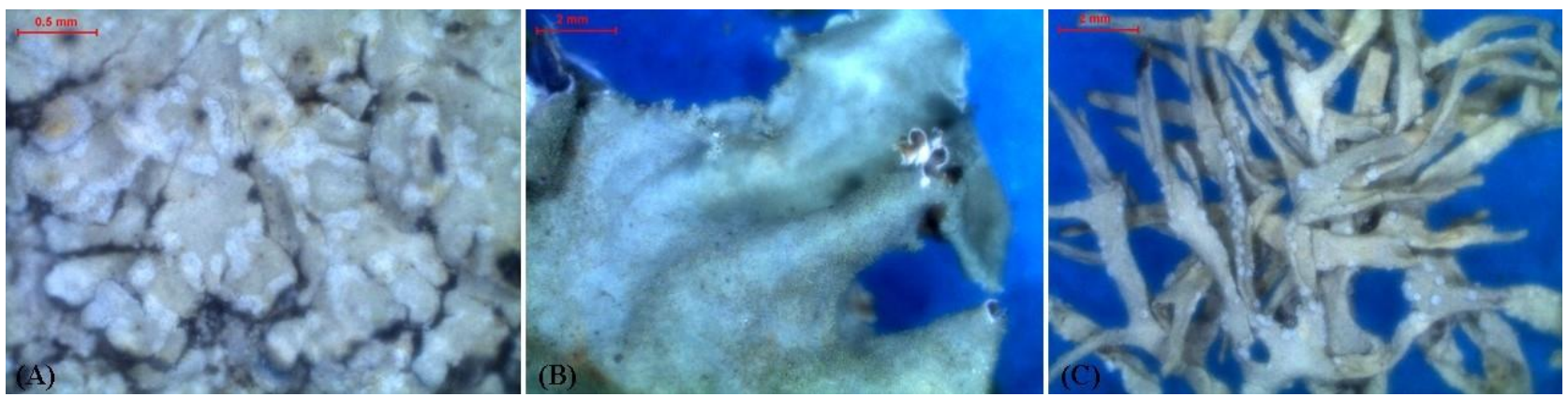

Fig. S1 - Microscopic images of A Dirinaria consimilis (Stirton) D. D. Awasthi. B Parmotrema tinctorum (Despr. ex Nyl.) Hale. C Roccella montagnei Bel. em. D. D. Awasthi. Scale bars: A $=0.5$ $\mathrm{mm}, \mathrm{B}, \mathrm{C}=2 \mathrm{~mm}$. 


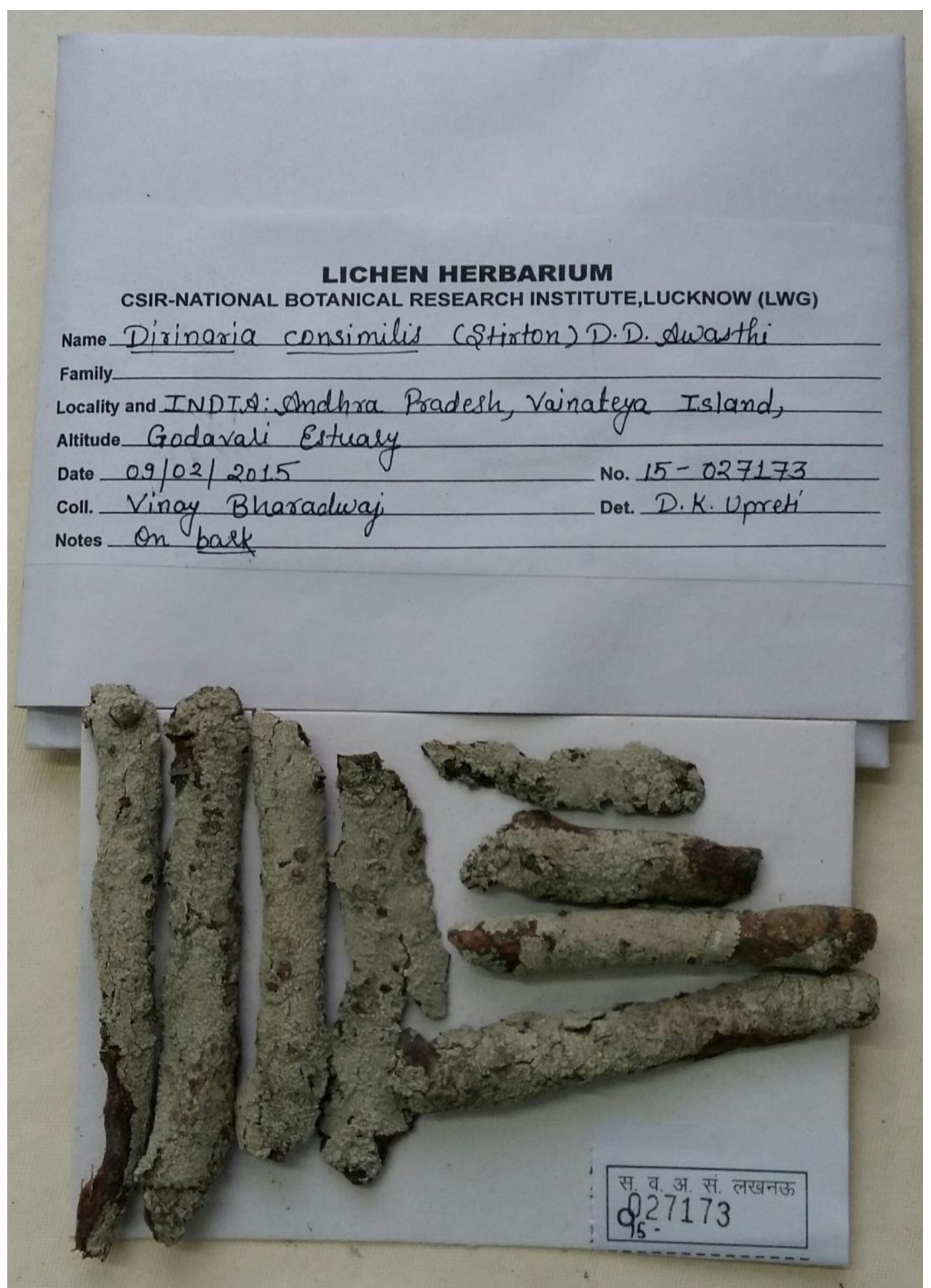

Fig. S2 - Lichen Herbarium of Dirinaria consimilis (Stirton) D. D. Awasthi. Scale bar: $1 \mathrm{~cm}$. 


\section{LICHEN HERBARIUM}

CSIR-NATIONAL BOTANICAL RESEARCH INSTITUTE,LUCKNOW (LWG)

Name Parmotrema tinctorum (Despr. ex Nyl.) Hale

Family

Locality and

Altitude

Date $0.9 / 04 / 2016$

Coll. Vinay Bharadwai

No. $16-027176$

Notes on twigs Det. D.K. Upreti

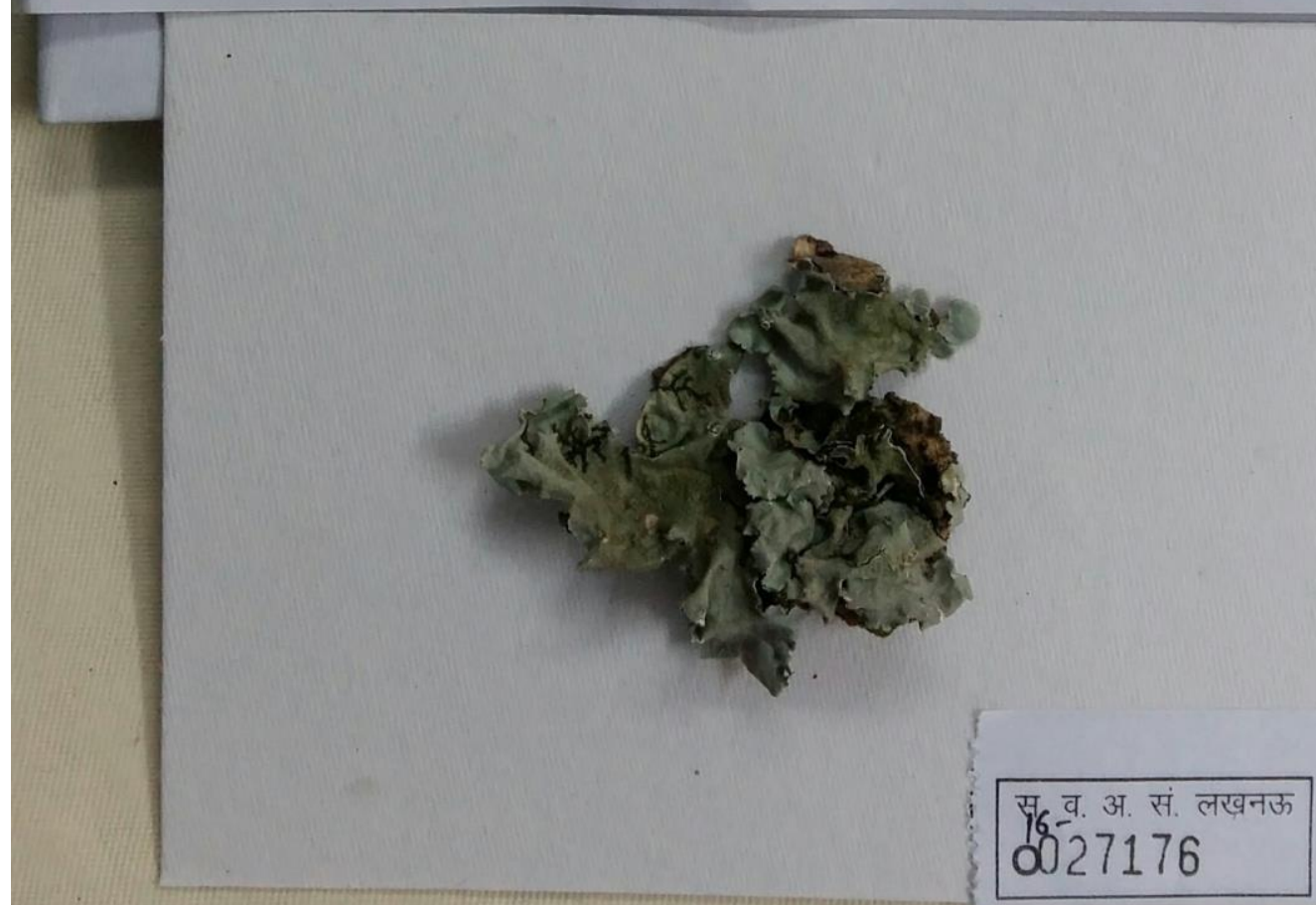

Fig. S3 - Lichen Herbarium of Parmotrema tinctorum (Despr. ex Nyl.) Hale. Scale bar: 1 cm. 


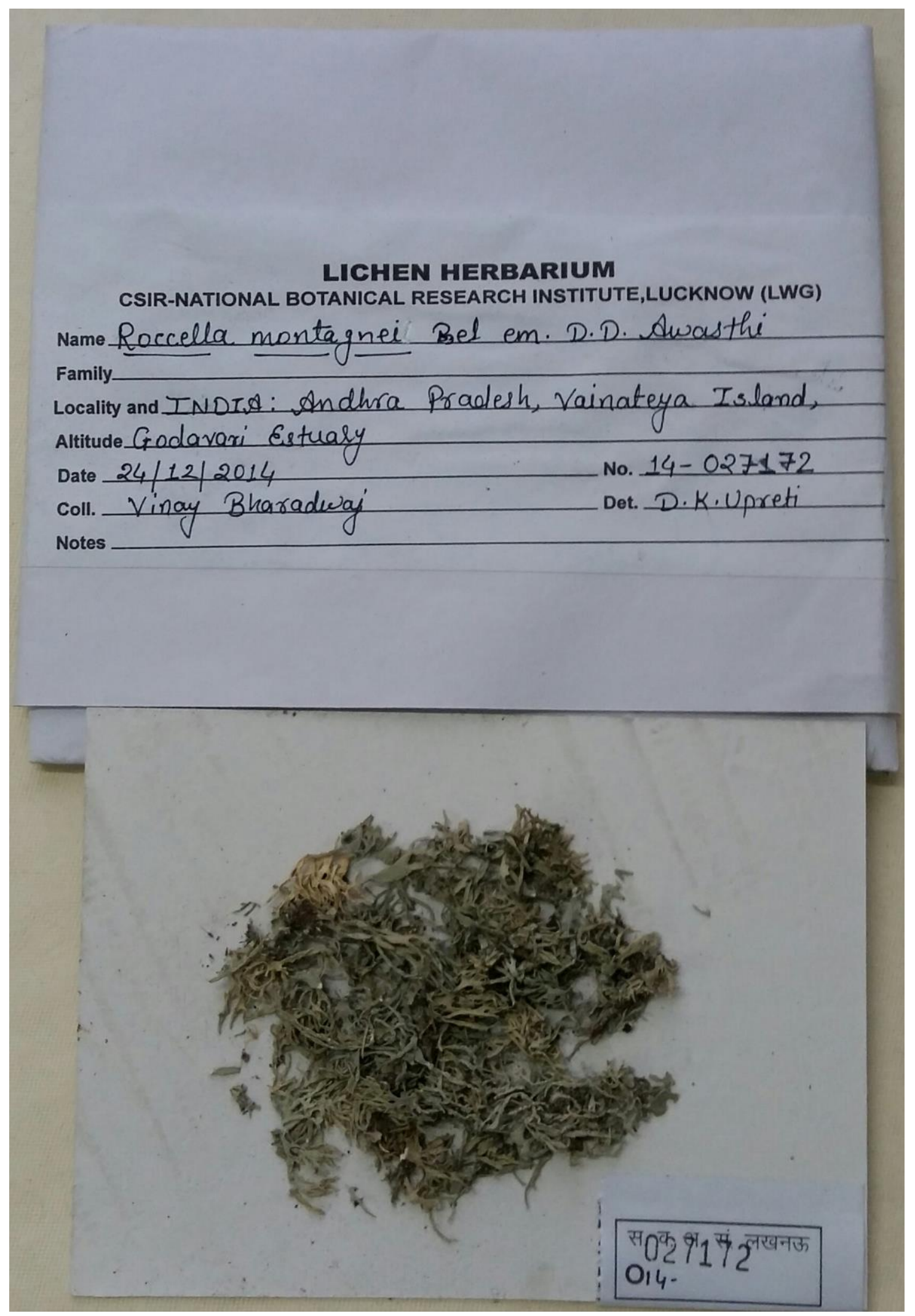

Fig. S4 - Lichen Herbarium of Roccella montagnei Bel. em. D. D. Awasthi. Scale bar: $1 \mathrm{~cm}$. 